\title{
Access of the black population to health services: integrative review
}

\author{
Acesso da população negra a serviços de saúde: revisão integrativa \\ Acceso de la población negra a servicios de salud: una revisión integrativa
}

\begin{abstract}
Nelma Nunes da Silva'
ORCID: 0000-0003-2790-1792

Veronica Batista Cambraia Favacho'

ORCID: 0000-0003-0526-119X

Gabriella de Andrade Boska"

ORCID: 0000-0002-5827-6486

Emerson da Costa Andrade"II

ORCID: 0000-0002-4370-3975

Neuri Pires das Merces'III

ORCID: 0000-0001-5900-2412
\end{abstract}

Márcia Aparecida Ferreira de Oliveira"

ORCID: 0000-0002-1069-8700

'Universidade Federal do Amapá. Macapá, Amapá, Brazil. "Universidade de São Paulo. São Paulo, São Paulo, Brazil. "'Secretaria Municipal de Saúde de São Paulo. São Paulo,

São Paulo, Brazil.

How to cite this article: Silva NN, Favacho VBC, Boska GA, Andrade EC, Merces NP, Oliveira MAF. Access of the black population to health services: integrative review.

Rev Bras Enferm. 2020;73(4):e20180834.

doi: http://dx.doi.org/10.1590/0034-7167-2018-0834

Corresponding author:

Veronica Batista Cambraia Favacho

E-mail:vv.favacho@gmail.com

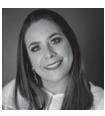

EDITOR IN CHIEF: Antonio José de Almeida Filho ASSOCIATE EDITOR: Andrea Bernardes

\section{ABSTRACT}

Objectives: demonstrate and discuss how the black population's access to health services occurs Methods: integrative literature review with the following question: How does the black population's access to health services occur? The search was carried out in the Scholar, LILACS and SciELO databases and used the descriptor "access to health services" and the term "population," resulting in a sample with twelve articles. Results: studies show that the difficulty of access is a fundamental factor for the quality of life of people, directly compromising preventive services, especially for women's health and, in addition, it has significant impact on the illness process of the black population within its particularities. Final Considerations: several limiting factors compromise the black population's access to health services, including institutional and structural factors

Descriptors: African Continental Ancestry Group; Health Services Accessibility; Health of Ethnic Minorities; Primary Health Care; Health Policy.

\section{RESUMO}

Objetivos: evidenciar e discutir como ocorre o acesso da população negra aos serviços de saúde. Métodos: revisão integrativa da literatura com a seguinte pergunta: Como ocorre o acesso da população negra aos serviços de saúde? A busca foi realizada nas bases de dados Scholar, LILACS e SciELO e utilizou o descritor "acesso aos serviços de saúde" e o termo "população", resultando em uma amostra de doze artigos. Resultados: estudos demonstram que a dificuldade de acesso é um fator fundamental para a qualidade de vida das pessoas, comprometendo diretamente serviços preventivos, principalmente para a saúde da mulher e, ainda, é impactante para o processo de adoecimento da população negra dentro de suas particularidades. Considerações Finais: diversos fatores limitantes comprometem o acesso da população negra aos serviços de saúde, desde institucionais a estruturais. Descritores: Grupo com Ancestrais do Continente Africano; Acesso aos Serviços de Saúde; Saúde das Minorias Étnicas; Atenção Primária à Saúde; Política de Saúde.

\section{RESUMEN}

Objetivos: exponer y discutir cómo ocurre el acceso de la población negra a los servicios de salud. Métodos: revisión integrativa de la literatura a partir de la siguiente pregunta: ¿Cómo ocurre el acceso de la población negra a los servicios de salud? Se realizó una búsqueda en las bases de datos Scholar, LILACS y SciELO, utilizando el descriptor "acceso a los servicios de salud" y el término "población", lo que resultó en una muestra con 12 artículos. Resultados: los estudios demuestran que la dificultad de acceso es un factor fundamental para la calidad de vida de las personas, lo que afecta directamente los servicios preventivos, principalmente en la salud de la mujer e impacta más aún en el proceso de padecimiento de la población negra dentro de sus particularidades. Consideraciones Finales: diversos factores limitantes afectan el acceso de la población negra a los servicios de salud, desde institucionales hasta estructurales.

Descriptores: Grupo de Ascendencia Continental Africana; Accesibilidad a los Servicios de Salud; Salud de las Minorías Étnicas; Atención Primaria de Salud; Política de Salud. 


\section{INTRODUCTION}

In Brazil, the black population comprised $54 \%$ of the total population in the period from 2000 to 2010. Considering all blacks and browns, it was observed that there was a significant percentage increase of this population, $27.6 \%$, higher than Brazil's populational growth in that same decade, which was $12.3 \%$, also observing a more significant variation when comparing blacks $(37.6 \%)$ and browns $(26.0 \%)^{(1)}$.

The majority of the black population has less qualified jobs and worse remuneration in the labor market; resides in areas with no or low availability of basic infrastructure services; suffers greater restrictions on access to health services and these, when available, are of poorer quality and lower efficiency ${ }^{(2)}$. Even so, until recently, there was a strong resistance to the understanding that these disparities could be attributed, at least in part, to the racial inequalities existing in Brazilian society. Only from the 1990 s onwards, Brazil began to recognize the racial difference as one of the factors of social inequality ${ }^{(2)}$.

Important actions have already been taken to minimize the damage suffered by the black population in Brazil, such as the quota system - reservation of vacancies for blacks, indigenous, people with disabilities, public school and low income students in universities, public procurement and labor market--, the creation of the National Policy for Complete Health of the Black Population and the possibility of indicting for racist and discriminatory actions whenever a person has some limitation of access to work, education or health because of their race, skin color, sex or age, as not all discriminatory actions are explicit or declared ${ }^{(3)}$.

The Brazilian black population has epidemiologic and social vulnerabilities that result, for example, in difficulties in accessing health services. This condition was found in many Brazilian studies that also demonstrate difficulties in accessing health services and establish a relation with processes of racial stigmatization. These situations compromise the lives of individuals, regarding the conditions of survival and health ${ }^{(3-4)}$.

National studies in the field of health using the race/color variable are scarce, but some of them show a high occurrence of illness and death of this population. The explanations presented for the fact are limited to the interpretation based on poverty, characterizing a racist discourse. Accordingly, race/color should not be understood from the biological point of view, but as a social category that carries with it the load of historical and cultural constructions, representing an important determinant for the lack of equity in health concerning racial groups ${ }^{(5)}$.

Thus, this study proposal is still insufficient, especially when compared to other areas of knowledge, providing research opportunities to fill the gaps on the subject. Therefore, it is fundamental to discuss how the black population's access to health services occurs nowadays, as this may provide new perspectives on the nursing professional practice from the black population's point of view on access to health services.

\section{OBJECTIVES}

To demonstrate and discuss how the black population's access to health services occurs.

\section{METHODS}

This is a qualitative study to find productions on the subject of the black population's access to health services, between 2006 and 2018. The integrative literature review was adopted, a type of study that enables that knowledge about a given subject is traced, analyzed and presented succinctly, highlighting its relevance.

The synthesis of knowledge, indispensable for its applicability in the field of practice ${ }^{(6)}$, encompasses experimental and non-experimental studies and aims to gather and synthesize the knowledge already produced on the topic investigated, allowing to seek, evaluate and synthesize the available evidence for its incorporation into practice. Thus, it contributes to the process of systematization and analysis of results aiming at comprehending a given theme ${ }^{(6)}$.

Six steps were carried out to construct the integrative literature review: 1) selection of the research question; 2) definition of criteria for inclusion and exclusion of studies and selection of the sample; 3 ) representation of the selected studies in table format; 4) critical analysis of the findings; 5 ) interpretation of the results; and 6) presentation, in a clear way, of the evidence found ${ }^{(6)}$.

The theme of this review is based on a guiding question formulated through the PICo ( $\mathrm{P}=$ Patient or Problem, I=Intervention, $\mathrm{Co}=$ Context) strategy ${ }^{(7)}$ : how does the black population's access to health services occur?

The review was conducted in the Scholar, LILACS, and SciELO databases and was based on the descriptors "grupo com ancestrais do continente africano"; "acesso aos serviços de saúde"; "saúde da população negra", "African continental ancestry group"; "health services"; "health of ethnic minorities"; "primary health care"; "health policy", combined with the Boolean operator "AND".

The inclusion criteria for the articles were defined as follows: all article categories (original, literature review, reflection, update, experience report, and others); articles with abstracts and full texts available for analysis; articles published in Portuguese, English, or Spanish, between 2006 and 2018 and which answered the guiding question.

Exclusion criteria were: articles unavailable during the study period; repeated productions (between databases), and that did not expressively answer the guiding question.

The next step was the interpretation and comparison between the productions and the elements contained in each one, finding significant elements and evidences about how the literature has referred to the access of the black population to health services.

We excluded repetitions from the material obtained - 711 articles - and applied filters, with 176 items remaining. After this step, we thoroughly read each abstract, remaining 53 items for analysis, highlighting those that met the objective proposed by this study, in order to organize and tabulate the data. Following the inclusion criteria, 12 studies were selected for analysis, which are referenced in the present text (Figure 1). For the organization and tabulation of the data, a collection instrument was prepared containing: citation (title, periodical, year of publication and authors), country of the study, study category, nature of the study, theoretical framework, method of analysis, focus, profile of the participants (sex, age , mean educational level, income), access to health (focusing on the diversity and potential of the services to ensure access). 


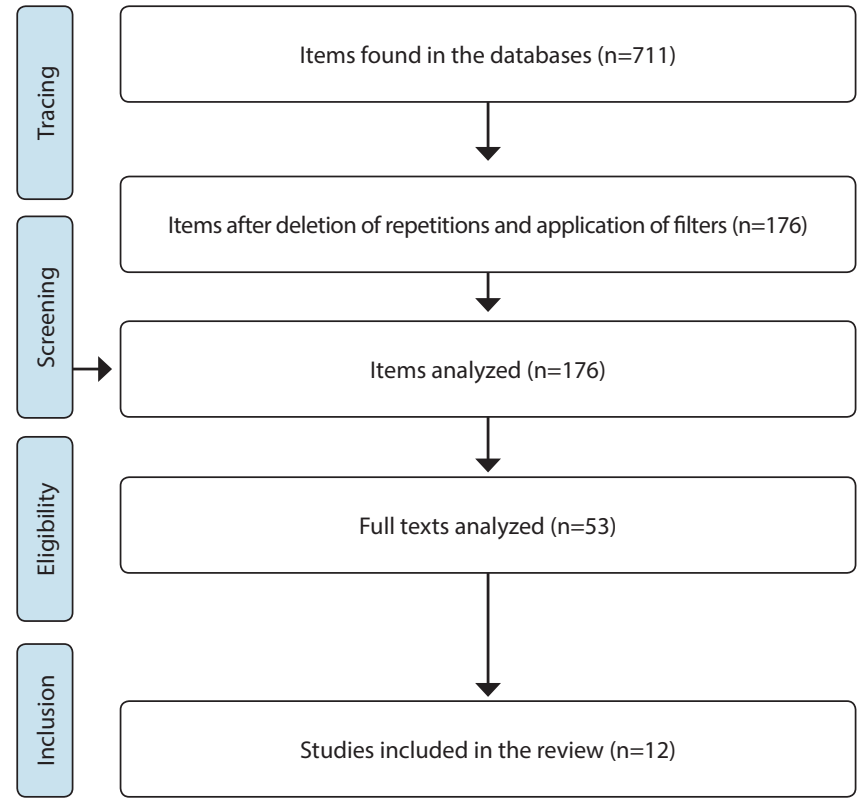

Figure 1 - Flowchart of the systematization of the search for articles in the databases, Brazil, 2019

Subsequently, bibliometric analysis was performed to characterize the selected studies according to title, author, year, country, design, objective(s), and results (Chart 1). The studies were compared and grouped by similarity of content, in the form of empirical categories, and four categories were constructed for analysis.

\section{RESULTS}

In Chart 1, presents the characterization of the studies selected.

It can be observed that $42 \%$ (5) were published in international periodicals $^{(9,10,13,17-18)}$ and $58 \%$ (7) in national periodicals $s^{(4,8,11-12,14-16)}$. The countries of origin of the studies were distributed as follows: Brazil 58\% (7)(4,8,11-12,14-16), United States (USA) 25\% (03)(13,17-18), other countries $17 \%$ (2), namely Colombia (1) ${ }^{(9)}$ and South Africa $(1)^{(10)}$. The selected studies were classified as to the category of

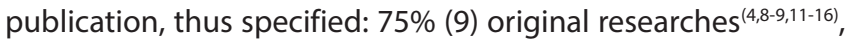
$25 \%$ (3) reflection and review articles ${ }^{(10,17-18)}$.

The articles were categorized as to the methodological paradigm of the study, and were distributed as follows: $17 \%$ (2) qualitative studies ${ }^{(4,9)}, 50 \%(6)$ quantitative studies ${ }^{(8,11,13-16)}, 8 \%$ (1) quantitativequalitative studies ${ }^{(12)}$, and $25 \%$ (3) others (review articles ${ }^{(17-18)}$ and reflection articles $\left.{ }^{(10)}\right)$. As for the theoretical framework used in the studies, 92\% (11) did not specify it in the text and/or did not adopt a theoretical framework ${ }^{(4,8-13,16-18)}$ and $8 \%(1)^{(14)}$ adopted a theoretical framework.

In the classification of the studies as to the participants, $83 \%$ addressed the two sexes, male and female $(10)^{(8-10,12-17)}, 25 \%$ (3) only the female ${ }^{(4,11,18)}, 42 \%(5)$ addressed the elderly $(8,11-12,14,17)$, $25 \%$ children $^{(11,14)}$ and adolescents ${ }^{(18)}$.

As for educational level, $58 \%$ (7) had low educational level $(4,8,11-12,14,16-17)$ and $42 \%(5)$ others. Of these, $33.3 \%(4)$ did not report $^{(10,13,18-19)}$ and $8.3 \%(1)$ reported that the participants were university students ${ }^{(9)}$. Regarding income, $67 \%$ (7) of the analyzed articles discussed the item on low income $e^{(4,8-11,14,16-17)}$ and lack of income $^{(12)}, 25 \%$ did not refer to that ${ }^{(10,18-19)}$.

Chart 1 - Characterization of the articles selected for analysis, according to title, author, periodical, year, country and objective(s), Brazil (2019)

\begin{tabular}{|c|c|c|c|}
\hline $\begin{array}{l}\text { Title/author } \\
\text { year/country }\end{array}$ & $\begin{array}{c}\text { Design } \\
n=\end{array}$ & Objectives & Results \\
\hline $\begin{array}{l}\text { Utilização de serviços de saúde por } \\
\text { população quilombola do Sudoeste } \\
\text { da Bahia, Brasil. } \\
\text { Gomes KO et al. }{ }^{(8)}, 2011 . \\
\text { Brasil. }\end{array}$ & $\begin{array}{l}\text { Cross-sectional, } \\
\text { cohort } \\
\mathrm{n}=797\end{array}$ & $\begin{array}{l}\text { Analyze the use of health } \\
\text { services by the Quilombola } \\
\text { population of Vitoria da } \\
\text { Conquista, Bahia, Brazil. }\end{array}$ & $\begin{array}{l}\text { The prevalence of health services use by the Quilombola } \\
\text { population ( } 57.1 \% \text { ) was lower than that found in other } \\
\text { populations. In São Paulo, SP, and Pelotas, RS, the } \\
\text { prevalence of } 64.4 \% \text { and } 60.6 \% \text { of health services use } \\
\text { was observed, respectively. The services use proportion } \\
\text { in the last } 15 \text { days in these communities was low ( } 8.3 \% \text { ) } \\
\text { compared with national data ( } 13.4 \% \text { in } 1998,13.9 \% \text { in } \\
2003 \text {, and } 14.2 \% \text { in } 2008 \text { ). }\end{array}$ \\
\hline $\begin{array}{l}\text { Equidad de etnia en el acceso a } \\
\text { los servicios de salud en Bogotá, } \\
\text { Colombia. } \\
\text { Ariza-Montoya JF, Hernández- } \\
\text { Álvarez ME }{ }^{(9)}, 2007 \text {. Colombia. }\end{array}$ & $\begin{array}{l}\text { Qualitative, } \\
\text { documentary } \\
\text { study. } \\
\text { n=39 }\end{array}$ & $\begin{array}{l}\text { Trace inequalities in access to } \\
\text { health services resulting from } \\
\text { ethnicity in Bogotá. }\end{array}$ & $\begin{array}{l}\text { Ethnic inequalities exist in Bogotá, with regard to } \\
\text { access to health services, with evidence of violation of } \\
\text { rights, discrimination and lack of recognition of ethnic } \\
\text { differences. }\end{array}$ \\
\hline $\begin{array}{l}\text { Non-Adherence to antiretroviral } \\
\text { treatment by people living with HIV/ } \\
\text { AIDS in black communities in South } \\
\text { Africa: socio-cultural challenges. } \\
\text { Kheswa J(10), } 2014 \text {. } \\
\text { South Africa. }\end{array}$ & $\begin{array}{l}\text { Reflection } \\
\text { article. }\end{array}$ & $\begin{array}{l}\text { Provide an integrated approach } \\
\text { to strengthen the support base } \\
\text { necessary for adherence to } \\
\text { antiretroviral treatment. }\end{array}$ & $\begin{array}{l}\text { The results show that, due to discrimination and, } \\
\text { consequently, to the difficulty of access, people living } \\
\text { with HIV/AIDS experience more of its side effects, such } \\
\text { as depression and Kaposi's sarcoma, until death. }\end{array}$ \\
\hline $\begin{array}{l}\text { Mulheres negras e brancas e os níveis } \\
\text { de acesso aos serviços preventivos } \\
\text { de saúde: uma análise sobre as } \\
\text { desigualdades. } \\
\text { Goes EF, Nascimento } \mathrm{ER}^{(11)}, 2013 . \\
\text { Brazil. }\end{array}$ & $\begin{array}{l}\text { Descriptive and } \\
\text { quantitative } \\
n=10,291\end{array}$ & $\begin{array}{l}\text { Determine differentials } \\
\text { of the sociodemographic } \\
\text { characteristics and the levels of } \\
\text { access to preventive services of } \\
\text { women in Bahia, according to } \\
\text { race/color. }\end{array}$ & $\begin{array}{l}\text { The study shows that } 15.4 \% \text { of white women have a } \\
\text { good level of access, while only } 7.9 \% \text { of black women } \\
\text { have it. It is concluded that the barriers to access to } \\
\text { health services of black women are racial inequalities } \\
\text { and institutional racism. }\end{array}$ \\
\hline
\end{tabular}




\begin{tabular}{|c|c|c|c|}
\hline $\begin{array}{c}\text { Title/author } \\
\text { year/country }\end{array}$ & $\begin{array}{c}\text { Design } \\
n=\end{array}$ & Objectives & Results \\
\hline $\begin{array}{l}\text { Uso dos Serviços Públicos de Saúde } \\
\text { para DST/HIV/Aids por comunidades } \\
\text { remanescentes de quilombos no } \\
\text { Brasil. } \\
\text { Silva MJG, Lima FSS, } \\
\text { Hamann EM }{ }^{(12)}, 2010 . \\
\text { Brazil. }\end{array}$ & $\begin{array}{l}\text { Qualitative and } \\
\text { quantitative } \\
\qquad \mathrm{n}=218\end{array}$ & $\begin{array}{l}\text { Describe the conditions of } \\
\text { the black population's access } \\
\text { to diagnosis and care for STD, } \\
\text { HIV/Aids }\end{array}$ & $\begin{array}{l}\text { Black people have greater difficulties in health and } \\
\text { care services, complaints of STD symptomatology and } \\
\text { higher frequency of self-medication when compared } \\
\text { with non-blacks. }\end{array}$ \\
\hline $\begin{array}{l}\text { Acessibilidade à atenção básica a } \\
\text { famílias negras em bairro popular de } \\
\text { Salvador, Brasil. } \\
\text { Trad LA, Castellanos MEP, } \\
\text { Guimaraes } \mathrm{MCS}^{(4)}, 2012 \text {. } \\
\text { Brazil }\end{array}$ & $\begin{array}{l}\text { Ethnographical, } \\
\text { founded } \\
\text { on basic } \\
\text { anthropology } \\
\text { Interpretative. } \\
\text { n= } 42\end{array}$ & $\begin{array}{l}\text { Analyze the accessibility of } \\
\text { black families from a popular } \\
\text { neighborhood to primary } \\
\text { health care services. }\end{array}$ & $\begin{array}{l}\text { The barriers to access to health services that are } \\
\text { interposed between the provision of services and } \\
\text { the fulfillment of the black population's needs are } \\
\text { economic, organizational and cultural barriers. }\end{array}$ \\
\hline $\begin{array}{l}\text { The Influence of access related } \\
\text { factors on adherence to clinical } \\
\text { practice guidelines for muscle } \\
\text { invasive bladder cancer. } \\
\text { Stimson CJ et al. }{ }^{(13)}, 2014 \text {. } \\
\text { USA. }\end{array}$ & $\begin{array}{l}\text { Descriptive and } \\
\text { quantitative } \\
n=27,585\end{array}$ & $\begin{array}{l}\text { Test whether access-related } \\
\text { characteristics are associated } \\
\text { with adherence to guidelines } \\
\text { for invasive muscular bladder } \\
\text { cancer and whether the } \\
\text { association between access- } \\
\text { related characteristics and } \\
\text { adherence to guidelines varies } \\
\text { according to geographic region. }\end{array}$ & $\begin{array}{l}\text { Race, status of insurance, income and hospital volume } \\
\text { showed variation between regions as predictors of } \\
\text { treatment with radical cystectomy/dissection of pelvic } \\
\text { lymph nodes. }\end{array}$ \\
\hline $\begin{array}{l}\text { Comunidade quilombola: análise } \\
\text { do problema persistente do acesso à } \\
\text { saúde, sob o enfoque da Bioética de } \\
\text { Intervenção. } \\
\text { Vieira ABD, Monteiro } \operatorname{OS}^{(14)}, 2013 . \\
\text { Brazil. }\end{array}$ & $\begin{array}{l}\text { Descriptive and } \\
\text { quantitative } \\
\qquad \mathrm{n}=12\end{array}$ & $\begin{array}{l}\text { Contextualize the socio- } \\
\text { epidemiological profile related } \\
\text { to the living conditions of } \\
\text { the Kalunga Quilombola } \\
\text { community from the } \\
\text { perspective of Intervention } \\
\text { Bioethics. }\end{array}$ & $\begin{array}{l}\text { The results indicate problems related to social and } \\
\text { health issues, difficulties in promoting the inclusive } \\
\text { processes of universality and equity in health for blacks. }\end{array}$ \\
\hline $\begin{array}{l}\text { Política Nacional de Saúde } \\
\text { Integral da População Negra: } \\
\text { implementação, conhecimento } \\
\text { e aspectos socioeconômicos sob } \\
\text { a perspectiva desse segmento } \\
\text { populacional. } \\
\text { Neto JAC }{ }^{(15)}, 2014 . \\
\text { Brazil. }\end{array}$ & $\begin{array}{l}\text { Cross-sectional, } \\
\text { descriptive, } \\
\text { quantitative } \\
\quad \mathrm{n}=391\end{array}$ & $\begin{array}{l}\text { Investigate the black } \\
\text { population's knowledge about } \\
\text { the policy, its potential benefits } \\
\text { and the difficulties of access to } \\
\text { health. }\end{array}$ & $\begin{array}{l}\text { About } 90 \% \text { of respondents reported not knowing the } \\
\text { existence of a health policy for the black population } \\
\text { and } 53 \% \text { declared a possible racial discrimination. } \\
\text { When asked about the black population's access to } \\
\text { health, the black people considered this access to be } \\
\text { more difficult }(56.4 \%) \text {. }\end{array}$ \\
\hline $\begin{array}{l}\text { Oportunidade perdida para } \\
\text { diagnóstico oportunista de diabetes } \\
\text { Mellitus em comunidades quilombolas } \\
\text { do sudoeste da Bahia, Brasil. } \\
\text { Souza CL, Barroso SM, } \\
\text { Guimarães MDC }{ }^{(16)}, 2013 \text {. } \\
\text { Brazil. }\end{array}$ & $\begin{array}{l}\text { Population- } \\
\text { based, cross- } \\
\text { sectional. } \\
\quad \mathrm{n}=548\end{array}$ & $\begin{array}{l}\text { Estimate the prevalence and the } \\
\text { factors associated with the loss } \\
\text { of opportunities for diagnosing } \\
\text { Diabetes (PDO) in Quilombola } \\
\text { communities, located in } \\
\text { the rural area of Vitória da } \\
\text { Conquista, Bahia, Brazil. }\end{array}$ & $\begin{array}{l}\text { The loss of opportunity for opportunistic diagnosis } \\
\text { (PDO) of DM in this population was } 42.6 \% \text { and } \\
\text { corroborates data from other studies on PDO. The index } \\
\text { of access to services was evaluated as poor in } 28.4 \% \\
\text { of the individuals. A proportion of self-reported DM of } \\
8.2 \% \text {, higher than the Brazilian average of } 5.6 \% \text {. }\end{array}$ \\
\hline $\begin{array}{l}\text { Assessing equitable care for } \\
\text { Indigenous and Afro descendant } \\
\text { women in Latin America. } \\
\text { Castro A, Savage V, Kaufman } \mathrm{H}^{(17)} \text {, } \\
2015 . \\
\text { USA. }\end{array}$ & $\begin{array}{l}\text { Literature } \\
\text { review. }\end{array}$ & $\begin{array}{l}\text { Trace and understand } \\
\text { the barriers to equitable } \\
\text { care within the health } \\
\text { environments that women of } \\
\text { ethnic minorities find in Latin } \\
\text { America and examine possible } \\
\text { strategies to mitigate the } \\
\text { problem. }\end{array}$ & $\begin{array}{l}\text { Health provider discrimination against indigenous and } \\
\text { Afro-descendant women is a primary barrier for access } \\
\text { to quality health in Latin America. Discrimination is } \\
\text { motivated by prejudice against populations of ethnic } \\
\text { minorities, women and the poor in general. }\end{array}$ \\
\hline $\begin{array}{l}\text { O encontro mais estranho de todos: } \\
\text { discriminação étnica e racial no } \\
\text { sistema de saúde dos Estados Unidos. } \\
\text { Sherman } \mathrm{AJ}^{(18)}, 2017 . \\
\text { USA. }\end{array}$ & $\begin{array}{l}\text { Literature } \\
\text { review. }\end{array}$ & $\begin{array}{l}\text { Selectively analyze studies } \\
\text { published after } 2003 \text { on the } \\
\text { probable contribution of the } \\
\text { unconscious bias of physicians } \\
\text { to the disparities of U.S. health } \\
\text { services. }\end{array}$ & $\begin{array}{l}\text { The reviewed studies found an unconscious "pro- } \\
\text { white" bias in the attitudes of physicians in relation to } \\
\text { interactions with patients, although some evidence } \\
\text { suggests that black and female physicians may be less } \\
\text { prone to this bias. Limited social contact between white } \\
\text { physicians and racial/ethnic minorities outside medical } \\
\text { environments, as well as severe time pressures that } \\
\text { physicians often face during encounters with patients } \\
\text { who have complex health problems, may increase their } \\
\text { susceptibility to the unconscious bias }\end{array}$ \\
\hline
\end{tabular}


In the classification of the studies as to the context in which they were performed in the area of interest, $58 \%$ (7) were related to hospital care and collective health $(4,8,10,12-13,16-19), 33.3 \%$ (4) only to collective health ${ }^{(11,14-18)}$, and $8.3 \%$ (1) only to hospital care ${ }^{(9)}$.

\section{DISCUSSION}

The information contained in these results reinforces the importance of this approach to the black population and the need for further studies that address access to health services, including preventive actions, emphasizing educational ones, which should be frequently prioritized for this population, aiming to reduce this gap in science as to the population of blacks.

Therefore, analysis of the information of the selected studies enabled organizing it into four categories: I - Users' access to the service; II - Factors limiting adherence; III - Professional and institutional difficulty to deal with diversity; and IV - Potential of the service to ensure access and adherence.

\section{Users' access to the service}

The demands of social movements related to the black population for greater and better access to the health system are not recent, as they have been present throughout the history of the mobilizations, since the post-abolition period, and intensified in the late twentieth century, even participating in the processes that generated the sanitary reform and the creation of the Unified Health System (SUS). However, this was not enough to include, in the SUS, explicit mechanisms to overcome the barriers faced by the black population in access to health, particularly those posed by racism ${ }^{(19)}$.

According to studies in Latin America (Argentina, Brazil, Bolivia, Chile, Colombia, Costa Rica, Cuba, Dominican Republic, Guatemala, Mexico and Peru), the obstacles that hamper the access of women from ethnic minorities include discrimination and violence within the health services ${ }^{(18)}$.

A study conducted in Bogotá presents reports such as: “[...] The appearance generates rejection and mockery [...] They speak aggressively, they speak hard and disgusted, sometimes there is and sometimes there isn't $[. . .]^{(9) "}$.

In this region, the indigenous and black have less access to institutional health services, as well as to preventive and curative services, compared with other peoples. The black population shows lower health conditions and has the lowest health insurance coverage ${ }^{(9)}$.

A disproportionately high number of black and poor people living in rural and urban areas in South Africa face barriers to access antiretrovirals, despite efforts made by the government. Scholars report that cultural beliefs, poverty, sorcery, lack of family support, gender-based violence, and substance abuse hinder the progress of HIV treatment programs. Stigma and discrimination are the main obstacles faced in seeking effective prevention of HIV/Aids and care, especially in sub-Saharan Africa ${ }^{(10)}$.

This stigma is rooted in the deviation from the social values and norms of a community and is a known risk factor for low levels of adherence to treatment, especially with antiretroviral drugs. Because of this and discrimination, the black population tends to often miss their doses, as a result of fear of being identified as HIV-positive, or as permanent patients of HIV treatment clinics ${ }^{(10)}$.
In Brazil, other factors that contribute to the difficulty of access are the levels of education and income, social and economic aspects determining the living conditions of a population in which black women are more exposed as to the aspect of poor access to health services ${ }^{(11)}$. While public employees have better access to preventive health services, a situation justified by their access to these services through health insurance plans. Black women with lower educational level had reduced access to adequate care, according to the standards established by the Brazilian Ministry of Health. Thus, it is observed that there are two levels of discrimination in society: educational and racial, which enter the level of care supplied by health services ${ }^{(11)}$.

Factors such as racism, sexism and socioeconomic and cultural conditions constitute structuring axes that act in a coordinated manner, affecting the guarantee of universal and equitable access to health. Access, although not the only factor responsible for a healthy and good quality life, contributes to maintaining a good state of health or to its recovery, because it refers to the use of services and inputs. Institutional racism is referred to as a barrier to access to preventative health services for black women ${ }^{(3,11)}$.

In a study conducted in the northeastern region of Brazil, it is affirmed that there are concrete difficulties in accessing services. As for supply, most communities have formal coverage from the Family Health Strategy (FHS), but the population needs care according to local group reports, because in some areas, as in dental care, there is a particularly critical gap, as reported by the respondents. This leads us to the need for a profound discussion and reformulation at the level of basic care, of the strategies for supply and organization of services. The research reaffirms the vulnerability of the black population in the issue of access and use of health services and the need for specific public policies geared toward these most vulnerable segments. It is worth mentioning the need for training and encouragement for the teams of the FHS programs, considering their importance in the care of these communities ${ }^{(12)}$.

In another study conducted in Bahia, there were the following reports of the respondents, after being questioned about racial discrimination:

Because I'm black? No. I think I've felt discriminated against because I'm poor. Because the others look at you like this. Sometimes they join both things. People discriminate against blacks thinking that blacks are poor. People that has noeducation, no culture, has nothing. (Flávia) ${ }^{(4)}$

The doctor holds the child like this [gesture with two fingers barely touching the skin], not even touches [...] with disgust of the children, even if he [the child] is bathed, cute, smelling good. That's like that, like that, because the child is black. (Clarissa) $)^{(4)}$

Actions such as these reduce the number of black users seeking care in the health system, characterizing racism in these institutions.

The inclusion of certain exposure variables related to access in this study was conducted by evidence indicating that access to high-quality health care is influenced by factors unrelated to the clinical presentation of the patient, including race, health insurance and availability of tertiary or high-capacity hospital centers. Race proved to be a well-established indicator of access, with non-white communities less likely receiving standard cancer therapies compared with white communities ${ }^{(13)}$. 
A study on the use of health services in Quilombola community evidenced that the prejudice practiced by health professionals is a potential factor that contributes to the non-access and non-use of health services by this populational group ${ }^{(8)}$.

\section{Factors limiting adherence}

As a result of racism, inequalities can cause diseases and illness, resulting in racial inequities in health. Aggregated factors, such as sexism, situate black women in a condition of greater vulnerability and violate the right to health and to quality access ${ }^{(11)}$.

The difficulties of adherence to treatments range from structural problems to difficulties to receive humane care in a given service. There is also a latent insufficiency in the health area, including the structure of services aimed at the provision of basic care, combined with the low availability of inputs and equipment, the reduced number of professionals, geographic barriers, and the depreciation of traditional medicinal knowledge of the culture of a given region ${ }^{(14)}$.

The higher morbidity and mortality of breast cancer in black populations and, mainly, low-income people, was also attributed to other factors, including the individual's diet, differences in the biology of tumors in black women, cultural and psychosocial factors, breastfeeding practices, multiple parity at younger ages, and other socioeconomic factors. Many have argued that there is disparity in the treatment among black women and low-income individuals who do not have health insurance, due to unequal access to better services ${ }^{(13)}$.

In many black communities, witchcraft is associated with HIV/ Aids infection and the belief in malignant spirits and witchcraft can lead to non-adherence to treatment. Thus, people who live with the disease believe that by performing rituals they will be purified and cured. Some of them understand the infection as a form of pollution - they often use the term "dirty blood" - and use laxatives and induce vomiting to cleanse the "dirt" of their blood. Studies have found that many South Africans who are reluctant to know their state of health cling to the myth that HIV/ Aids treatment was developed by white people to control blacks, and this also contributes to non-adherence ${ }^{(13)}$.

According to a study with Afro-descendants and indigenous in Latin America, that which may be an impediment keeping these women from seeking health services is the discrimination rooted in these same services. In addition, when they seek them, they are more exposed to receiving lower quality care or experiencing delays longer than other people. Besides the humiliation, exclusion and shame they feel in these contexts ${ }^{(18)}$.

\section{Professional and institutional difficulty to deal with diversity}

The failure of institutions and organizations lies in not supplying a professional service that respects diversity and is suited to people according to their color, culture, racial or ethnic origin. Which is shown in discriminatory norms, practices and behaviors adopted in the daily work routine as a result of racial prejudice, actions that combine racist stereotypes, lack of attention and ignorance. In any situation, institutional racism always situates people of racial or ethnic groups in conditions of disadvantage in access to benefits generated by the State and by other institutions and organizations ${ }^{(14)}$.

Thus, institutional racism sometimes presents itself in the form of verbal abuse - such as guilt, public humiliation, recrimination and offenses to the patient - generating feelings of shame and exclusion. Moreover, the negligence of health workers should also be considered as a form of this discrimination ${ }^{(18)}$.

Another study with U.S. physicians on racism in health care concluded that today, decades after the approval of the civil rights legislation of the 1960s, professionals routinely practice discrimination against people, considering the race factor as a predictor of this behavior ${ }^{(19)}$.

One of the studies evaluated reports that health care is performed by FHS teams, but there is precarious service, with a reduced number of units, teams and professionals, mainly physicians, dentists and nurses. It was observed that the Community Health Agent (CHA) is responsible for the follow-up of the Quilombola families. Although the National Policy for Complete Health of the Black Population (PNSIPN) guarantees the expansion of access and the quality of basic care, there was inconsistency between what is recommended and the actions implemented ${ }^{(14)}$.

\section{Potential of the service to ensure access and adherence}

As for potential, we highlight the Brazil Quilombola Program (PBQ), created by the Federal government as a policy that includes these communities through a set of integrated actions between various governmental agencies. The projects and actions proposed to enhance autonomous actions include: infrastructure development; basic sanitation; installation of social equipment in the communities; productive inclusion; economic and social development; and promotion of the social participation and control of Quilombola representatives in different levels to guarantee their rights and citizenship ${ }^{(14)}$.

Thus, the establishment of guidelines for the social visibility and inclusion of Quilombolas generates possibilities for reflection on the principle of equity, which can be translated through the organization of strategies that can reduce local social and sanitary inequalities. Ethnical-racial issues relating to access to services were hardly addressed.

Given the above, a potential reasoning would be that in the current context, in which there are government proposals and actions to reduce resources for social public policies, investments in health cannot be further reduced. Therefore, it is essential the joint effort of managers, workers and civil society to guarantee rights, considering the racial perversities in people's daily lives and their impact on health condition ${ }^{(20)}$.

Another point that deserves to be highlighted in the research on this subject would be a view from an intersectoral perspective, in which multiracial societies, such as the USA and Brazil, could be studied in a broader context, considering several complex and holistic concepts comprised in institutional racism in health - not only gender, race, educational level, and social class -, such as conceptions, lifestyles, beliefs and perceptions, in order to diminish and abolish this institutional and social behavior ${ }^{(19)}$.

Accessibility conditions are better understood in a multidimensional way, and four dimensions can be considered: political, 
economic-social, technical, and organizational ${ }^{(21)}$. The political dimension would involve the raising of awareness as to sanitation and social organization; the economic-social refers to the organization of the service network or the ease and difficulty related to the resort to health service; and the technical and organizational dimensions would involve aspects that characterize the service itself, such as hours of care service and quality of care ${ }^{(21)}$.

Other aspects could also be considered for the analysis of access to services, such as popular participation and social control, equity, coherence of services as to the needs of the population, strategies, tactics and allocation of resources and autonomy ${ }^{(21)}$.

This article found studies that demonstrate a decrease in access, mainly due to the technical and economic-social aspects. Regarding the technical aspect, there are situations such as differentiated care according to the race/color of the costumer ${ }^{(1)}$, which may occur due to different reasons, among them the health professional's prejudice against the race of the customer. The economic-social aspect refers to the studies that presented situations in which the client resides in rural areas or very distant from the health service, which would hinder their locomotion to the place of service ${ }^{(5)}$, as well as to those that found social and cultural characteristics that lead people to seek sorcerers to receive health care, rather than seeking the health service itself.

It is necessary to give meaning to the inequalities produced by racism, which impose to a population a set of vulnerabilities that does not constitute a new phenomenon, but which only assumes a new characterization over time, allowing the permanence of these conditions with the black population ${ }^{(22)}$.

In Brazil, health is considered a right of all and a duty of the State, understood as provider of health care to all equally, universally and equitably ${ }^{(23-24)}$. However, the legal guarantee of availability of services does not ensure the implementation of actions to provide access ${ }^{(21)}$. It is observed the need for reflection about the actions that should or could be implemented in seeking to supply access to health in its different aspects.

Implementing policies with the objective of promoting access to health services, hypothetically, would mean to address the dimensions that have meaning for those to whom the health service is intended ${ }^{(21)}$. In a country with the territorial dimensions of Brazil, it would be necessary, therefore, to develop studies to know cultural, social, economic and political aspects of the territory in which the health service is situated, or is meant to be situated ${ }^{(21)}$.

An adjustment is proposed between the health service and the community, which could be carried out by observing the following dimensions: availability, accessibility and acceptability ${ }^{(25)}$. Availability is understood as service factors that are within the reach of the community, that is, that which is supplied based on the existing demand; Accessibility comprises the direct and indirect costs that enable the community to seek the service; and Acceptability means the aspects that correspond to the subjective characteristics of the community in which the health service is situated, that is, its social and cultural aspects ${ }^{(25)}$.

With the participation of social movements in Brazil, the National Policy for Complete Health of the Black Population was created in 2009 , revised in 2013, seeking to meet the needs of this significant portion of the Brazilian population in full, considering their peculiarities, aiming at care, access, integrality, promotion, prevention, participatory management, social control, and permanent training for workers ${ }^{(26)}$. After the creation of the aforementioned policy, there was an increase in access, but there is still a need for evaluation and monitoring to check the quality of access and adherence supplied to this population. It is also necessary to raise the awareness of professionals as to dealing with diversity.

Data from analysis of adult mortality show more deaths among blacks than whites for cancer, circulatory diseases and congenital malformations (according to the mortality by the group of causes of death of the International Statistical Classification of Diseases and Related Health Problems, 10th revision (ICD-10). Mortality for blacks is twice as high as for whites in many situations, for example: mental illness; pregnancy, delivery and puerperium; infections; hematological, endocrine and dermatological diseases; and external causes ${ }^{(26)}$.

\section{Study limitations}

It is considered that this study has common limitations in an investigation with secondary data, since the information is already previously constructed. Thus, the studies found in the literature comprised a small number of articles that met the guiding question. New research proposals may be based on more international databases, for example in Psychology and/or in Social Sciences, which prioritize scientific knowledge, possibly not available through the databases chosen here. There is concern in the scientific environment regarding the health of the black population, but the databases with the descriptors of this study did not provide sufficient publications on how access and adherence to health services has occurred. It is believed that in-depth studies, especially on primary care, could bring elements about the proposed subject.

\section{Contributions to the field of nursing, health or public policies}

The knowledge generated by this review may support health care professionals with useful information in decision-making about the implementation of specific public policies, focusing on the black population's access and adherence to health services. Furthermore, as for clinical practice, it may contribute to continually rethink the humane care, treatment, prevention and promotion of health. In this context, the discussion groups, workshops, and community groups may improve the black population's self-confidence and stay in institutions, in addition to enhancing the services provided individually.

\section{FINAL CONSIDERATIONS}

The black population's access and adherence have several limiting factors that result in inadequate supply in health services, such as structural barriers, social and economic factors, professional performance, disrespect for cultural, ethnic, and racial diversity. Actions to improve access and adherence are already carried out, but there is a need for further monitoring and evaluation for their effective establishment.

Studies discussing this subject are necessary, demonstrating all the difficulties experienced by the black population to access health services, as well as the creation of strategies to reduce barriers--structural, cultural, and/or economic barriers--, making the health service more egalitarian, for blacks and non-blacks. 


\section{REFERENCES}

1. Silva TD, Góes FL. Igualdade racial no Brasil: reflexões no ano internacional dos afrodescendentes [Internet]. Brasília, DF: Ipea; 2013 [cited 2018 Mar 5]. 16 p. Available from: http://www.ipea.gov.br/portal/index.php?option=com_content\&view=article\&id=19034

2. Araújo EM, Costa MCN, Hogan VK, Araújo TM, Dias AB, Oliveira LA. The use of the variable of race/color within Public Health: possibilities and limits. Interface. 2009;13(31):383-94. doi: 10.1590/S1414-32832009000400012

3. Mário T, Jaccoud L, Osório R, Soares S. As políticas públicas e a desigualdade racial no Brasil: 120 anos após a abolição [Internet]. Brasília: Ipea; 2008 [cited 2018 Apr 13]. Available from: http://www.clam.org.br/bibliotecadigital/uploads/publicacoes/1107_1899_ Livrodesigualdadesraciais.pdf

4. Trad LAB, Castellanos MEP, Guimarães MCS. Accessibility to primary health care by black families in a poor neighborhood of Salvador, Northeastern Brazil. Rev Saúde Pública. 2012;6(46):1007-13. doi: 10.1590/S0034-89102012000600010

5. Lopes F. Experiências desiguais ao nascer, viver, adoecer e morrer: tópicos em saúde da população negra no Brasil. In: Fundação Nacional de Saúde (BR). Saúde da população negra no Brasil: contribuições para a promoção da equidade [Internet]. Brasília, DF: Funasa; 2005 [cited 2018 Apr 17]. p. 9-48. Available from: http://bvsms.saude.gov.br/bvs/pop_negra/pdf/saudepopneg.pdf

6. Claro HG, Oliveira MAF, Paglione HB, Soares RH, Okazaki C, Vargas D. Strategies and possibilities of motivational interviewing in adolescence: an integrative review. Texto Contexto Enferm. 2013;22(2):543-51. doi: 10.1590/S0104-07072013000200033

7. Santos CMC, Pimenta CAM, Nobre MRC. The PICO strategy for the research question construction and evidence search. Rev Latino-Am Enfermagem. 2007;15(3):508-11. doi: 10.1590/S0104-11692007000300023

8. Gomes KO, Reis EA, Guimarães MDC, Cherchiglia ML. [Use of health services by quilombo communities in southwest Bahia State, Brazil]. Cad Saúde Pública. 2013;29(9):1829-42. doi: 10.1590/0102-311X00151412 Portuguese.

9. Ariza-Montoya JF, Hernández-Álvarez ME. [Ethnic equity in accessing health services in Bogotá, Colombia, 2007]. Rev Salud Pública [Internet]. 2008 [cited 2018 May 16];10(1):58-71. Available from: https://scielosp.org/pdf/rsap/2008.v10suppl1/58-71/es Spanish.

10. Kheswa JG. Non-adherence to antiretroviral treatment by people living with HIV/AIDS in black communities in South Africa: socio-cultural challenges. Mediterranean J Soc Sci. 2014;5(14):450-57. doi: 10.5901/mjss.2014.v5n14p450

11. Goes EF, Nascimento ER. [Black and white women and the accessibility to preventive health services: an analysis of inequalities]. Saúde Debate. 2013;37(99):571-9. doi: 10.1590/S0103-11042013000400004 Portuguese.

12. Silva MJG, Lima FSS, Hamann EM. [Use of STD/HIV/AIDS-Oriented public health care services by Quilombo communities in Brazil]. Saúde Soc. 2010;19(2):109-20. doi: 10.1590/S0104-12902010000600011 Portuguese.

13. Stimson CJ, Resnick MJ, Patel SG, Zaid HB, Cookson MS, Penson DF, et al. The influence of access related factors on adherence to clinical practice guidelines for muscle invasive bladder cancer. Urology Practice. 2012;1(3):127-33. doi: 10.1016/j.urpr.2014.05.004

14. Vieira ABD, Monteiro PS. [Quilombola community: analysis of the persistent problem in health attention under the focus of the Intervention Bioethics]. Saúde Debate. 2013;37(99):610-18. doi: 10.1590/S0103-11042013000400008 Portuguese.

15. Chehuen Neto JAC, Fonseca GM, Brum IV, Santos JLCT, Rodrigues TCGF, Paulino KR, et al. [The National Comprehensive Health Policy for the Black Population: implementation, awareness and socioeconomic aspects from the perspective of this ethnic group]. Ciênc Saúde Colet. 2015;20(6):1909-16. doi: 10.1590/1413-81232015206.17212014 Portuguese.

16. Souza CL, Barroso SM, Guimarães MDC. [Missed opportunity for timely diagnosis of diabetes mellitus in Afrodescendant communities in the southwest of the state of Bahia, Brazil]. Ciênc Saúde Colet. 2015;19(6):1653-62. doi: 10.1590/1413-81232014196.08662013 Portuguese.

17. Castro A, Savage V, Kaufman H. Assessing equitable care for Indigenous and Afrodescendant women in Latin America. Rev Panam Salud Publica [Internet]. 2015 [cited 2019 Apr 16];38(2):96-109. Available from: https://www.ncbi.nlm.nih.gov/pubmed/26581050

18. James SA. The strangest of all encounters: racial and ethnic discrimination in US health care. Cad Saúde Pública. 2017;33(Suppl 1):e00104416. doi: 10.1590/0102-311×00104416

19. Werneck J. [Institutional racism and black population health]. Saude Soc. 2016;25(3):535-49. doi: 10.1590/s0104-129020162610 Portuguese.

20. Batista LE, Barros S. Confronting racism in health services. Cad Saúde Pública. 2017;33(Suppl 1):e00090516. doi: 10.1590/0102-311x00090516

21. Assis MMA, Jesus W. [Access to health services: approaches, concepts, policies and analysis model]. Ciênc Saúde Colet. 2012;17(11);2865-75. doi: 10.1590/S1413-81232012001100002 Portuguese.

22. Werneck J, editor. Mulheres negras: um olhar sobre as lutas sociais e as políticas públicas no Brasil [Internet]. Rio de Janeiro: Criola; 2010 [cited 2019 Mar 17]. 47 p. Available from: http://www.bibliotecadigital.abong.org.br/bitstream/handle/11465/886/81. pdf? sequence=1\&isAllowed $=y$

23. Governo Federal (BR). Lei no 8.080, de 19 de setembro de 1990. Diário Oficial da União[Internet].1990 Sept 20 [cited 2019 Mar 17]. Available from: https://www.planalto.gov.br/ccivil_03/LEIS/L8080.htm

24. Governo Federal (BR). Lei no 8.142, de 28 de dezembro de 1990. Diário Oficial da União[Internet].1990 Dec 31 [cited 2019 Mar 17]. Available from: http://www.planalto.gov.br/ccivil_03/Leis/L8142.htm. 
25. Ministério da Saúde (BR). Política Nacional de Saúde Integral da População Negra: uma política para o SUS/Ministério da Saúde [Internet]. Brasília, DF: Ministério da Saúde; 2013 [cited 2018 Oct 16]. Available from: http://bvsms.saude.gov.br/bvs/publicacoes/politica_nacional_ saude_integral_populacao.pdf

26. Batista LE. [Masculinity, race/color and health]. Ciênc Saúde Colet. 2005;10(1):71-80. doi: 10.1590/S1413-81232005000100013 Portuguese. 